\title{
Soil Chemical Properties and Maize (Zea mays L.) Yield influenced by Lime and Fern (Pteris vittata)
}

\author{
Nguyen Van CHUONG ${ }^{1, *}$ and Trang Kien BUSH ${ }^{2}$ \\ ${ }^{I}$ Department of Crop Science, Agricultural Faculty of An Giang University, Vietnam National University, \\ Ho Chi Minh City, Vietnam, Long Xuyen City, An Giang Province, Vietnam \\ ${ }^{2}$ Branch of Crop Production and Plant Protection of Kien Giang Province, Kien Giang, Vietnam
}

('Corresponding author's email: nvchuong@agu.edu.vn)

Received: 28 April 2020, Revised: 29 April 2021, Accepted: 6 May 2021

\begin{abstract}
This study aimed to investigate the influence of liming and fern on reducing the absorption of arsenic (As) by maize and As content in the soil. The single-factor experiment was designed in a completely random block ( 4 treatments and 4 replicates). Treatments were followed: Treatment 1 (NT1) liming (3tons $\mathrm{CaO} \cdot \mathrm{ha}^{-1}$ ); NT2: Plant ferns alternately with maize (without liming); NT3: Plant ferns alternately with maize and liming (3 tons $\mathrm{CaO} \cdot \mathrm{ha}^{-1}$ ); NT4: Control (no liming or ferns). The results showed that the applications of liming and ferns have positive influences on the soil $\mathrm{pH}, \mathrm{EC}, \mathrm{OM}$, yield, and yield components of the maize tested in this study. The yield difference between the application of liming and intercropped ferns was increased from 5.4 to $22.3 \%$. Moreover, the arsenic contents in soil, stems, and seeds were 25.7, 32.0 and $50 \%$ lower than that of the control, respectively. Also, the results showed the As absorbability of ferns from soil to roots and stems, which significantly caused reduction of a large amount of As content in soils. Therefore, to reduce the production cost, and enhance soil and maize quality, application of lime ( 3 ton.ha $\left.{ }^{-1}\right)$ and intercropped ferns is recommended.
\end{abstract}

Keywords: Arsenic, Chemical properties of soil, Fern (Pteris vittata), Liming, Maize (Zea mays L.)

\section{Introduction}

Maize (Zea mays L.) is the most cultivated economic cereal (including maize, rice, wheat, oats and barley) in the world, and constitutes a staple food for humans in most developing countries of Latin America, Africa, and Asia [1]. Previous studies have shown concerns about the risks of arsenic (As) accumulation in maize [2,3]. Maize has a lower bio-concentration factor (BCF) for soil as compared to rice and leafy vegetables [4]. However, comparisons between the abilities of different maize cultivars to accumulate As and studies of the stability of accumulated As among different cultivars are rare [5]. Furthermore, it is still debatable whether maize is a suitable substitute for other crops with high As accumulation when planting in As-contaminated farmlands. For example, maize showed low As accumulation in its grain and was suitable for growing in As-contaminated soils [6]. Also, As concentration in maize grains was far below the national food safety standard for maize in China, and the As exposure risk to humans could be reduced by choosing maize as a substitute in As-contaminated farmlands [7]. However, maize had high bio accumulation and high exposure risks to As in high-As soils [8]. The grain of As concentration in some maize cultivars exceeded the safe limit and could pose potential threats to human health [9]. Some chemical inactivators are recommended to be applied to Ascontaminated farmlands to reduce As uptake by maize [10].

The phenomenon of metal hyperaccumulation by plants has considerable importance in phytoremediation, more specifically phytoextraction [9]. The key process of phytoextraction in this study 
demonstrated that As promoted growth in hyperaccumulators and enhanced Fe, $\mathrm{P}, \mathrm{K}$ and $\mathrm{Zn}$ uptake. Different plant growth responses to As among hyperaccumulators $P$. ensiformisand, $P$. multifida, and non-hyperaccumulator $P$. ensiformis, may help to better understand why hyperaccumulators grow better under As-stress [2]. During growth and development, some plant species are effective at absorbing arsenic. Results have shown that the biomass, photosynthetic pigment contents, antioxidant enzyme activity, and uptake of As in $P$. vittata L. were significantly enhanced by co-planting with $M$. alba L. or $B$. papyrifera L. Especially, the uptake of As by $P$. vittata $L$. was significantly $(\mathrm{p}<0.05)$ increased by 80.0 and $64.2 \%$ when it was co-planted with M. alba L. or B. papyrifera L., respectively, while the As, $\mathrm{Cd}, \mathrm{Pb}$ and $\mathrm{Zn}$ contents of both $M$. alba $\mathrm{L}$. and $B$. papyrifera $\mathrm{L}$. were not significantly promoted by the co-planting [11].

A fern (Pteris vittata) grows in arsenic-contaminated soils and accumulates large amounts of As in its above ground biomass. Pteris vittatais tolerant of high concentrations of As, up to 1,500 mg As. $\mathrm{kg}^{-1}$ soil. In a study where $P$. vittata was grown under a controlled environment in soil spiked with $98 \mathrm{mg}$ As per $\mathrm{kg}$, the bio concentration factor (the ratio of As in the plant tissue: Water-soluble As in the soil) was 1,450, and the translocation factor (As in the shoot: As in the root) was 24 [11]. Pteris vittata accumulates most of the As in its fronds, with little in the roots [11], suggesting a very efficient As translocation. About $26 \%$ of the original soil As was removed by the $P$. vittata after 20 weeks of growth [11]. It was proposed that $P$. vittata is an excellent model to study As uptake, translocation, speciation, distribution, and detoxification in plants and for phytoremediation of As-contaminated soil and water [11].

Arsenic (As) can accumulate in the edible parts of crops and can, thus, enter the food chain, posing a risk to human health [12]. Recently, phytoremediation [13], chemical immobilization [14], and leaching [15] have been used in the remediation of agricultural farmlands. In the long-term, these techniques accrue huge economic costs, time requirements, and risk over-remediation, which can negatively affect soil texture and fertility, making these processes unsuitable to meet the demands of agricultural production. Substitution planting with crops capable of low-As uptake has been regarded as a highly efficient measure to reduce or avoid As accumulation in agricultural products [10].

A range of liming materials available includes limes tone $\left(\mathrm{CaCO}_{3}\right)$, burnt lime $(\mathrm{CaO})$, slaked lime $\left[\mathrm{Ca}(\mathrm{OH})_{2}\right]$, dolomite $\left[\mathrm{CaMg}\left(\mathrm{CO}_{3}\right)_{2}\right]$, and slag $\left(\mathrm{CaSiO}_{3}\right)$, varying in their acid-neutralizing capacity [16]. Decreasing mobility of elements such as arsenic, cadmium, copper, zinc, nickel, and lead in limed soil, and effective decrease of their element uptake by several crops, was intensively investigated in both pot and field conditions [17]. The application of lime combined with rice husk ash, which reduces arsenic uptake and increases soybean yields, may be the only input to improving soil fertility that farmers can obtain at an early cost investment which is very low [18]. The addiction of lime combined with ferns, a farmer can raise his yield and income. This study aimed to investigate the effects of lime fertilizer combined with plant ferns on arsenic and the improvement of the quality of crop soil in Quoc Thai, An Giang province, Vietnam.

\section{Materials and methods}

\section{Study area and study species}

The study experimented in the field in Quoc Thai, An Phu district, An Giang province, from December 2018 to April 2019. Each of the pots was fertilized with a basal dose of N, P, and K at 40, 60, and $50 \mathrm{~kg} \cdot \mathrm{ha}^{-1}$, respectively. Maize (NK4300) were sown in each pot, and the germinated plants were later thinned to keep 3 plants per pot.

\section{Study design and data collection}

The experiment was carried out in the field at areas inside the dike with 4 treatments (NT): NT1: liming (3 tons $\mathrm{CaO} \cdot \mathrm{ha}^{-1}$ ); NT2: Plant ferns alternately with maize (without liming); NT3: Plant ferns alternately with maize and liming ( 3 tons $\mathrm{CaO} . \mathrm{ha}^{-1}$ ); NT4: Control (no liming or ferns) and 4 replications (Figure 1). The kind of irrigation water used was (deep well water) $\times 2$ doses of lime $\left(5\right.$ tons.ha $\left.^{-1}\right)$ and ferns, with an area of each replicate of being equivalent to $24 \mathrm{~m}^{2}\left(6 \times 4 \mathrm{~m}^{2}\right)$, planted in a single row with a distance of $50 \times 30 \mathrm{~cm}^{2}\left(3\right.$ seeds.hole $\left.{ }^{-1}\right)$. Ferns were planted between maize plants in NT2 and NT3. The 
distance between plants was $30 \mathrm{~cm}$ and the row was $50 \mathrm{~cm}$. After 10 weeks of growth, the above ground biomass of the maize plants was harvested.

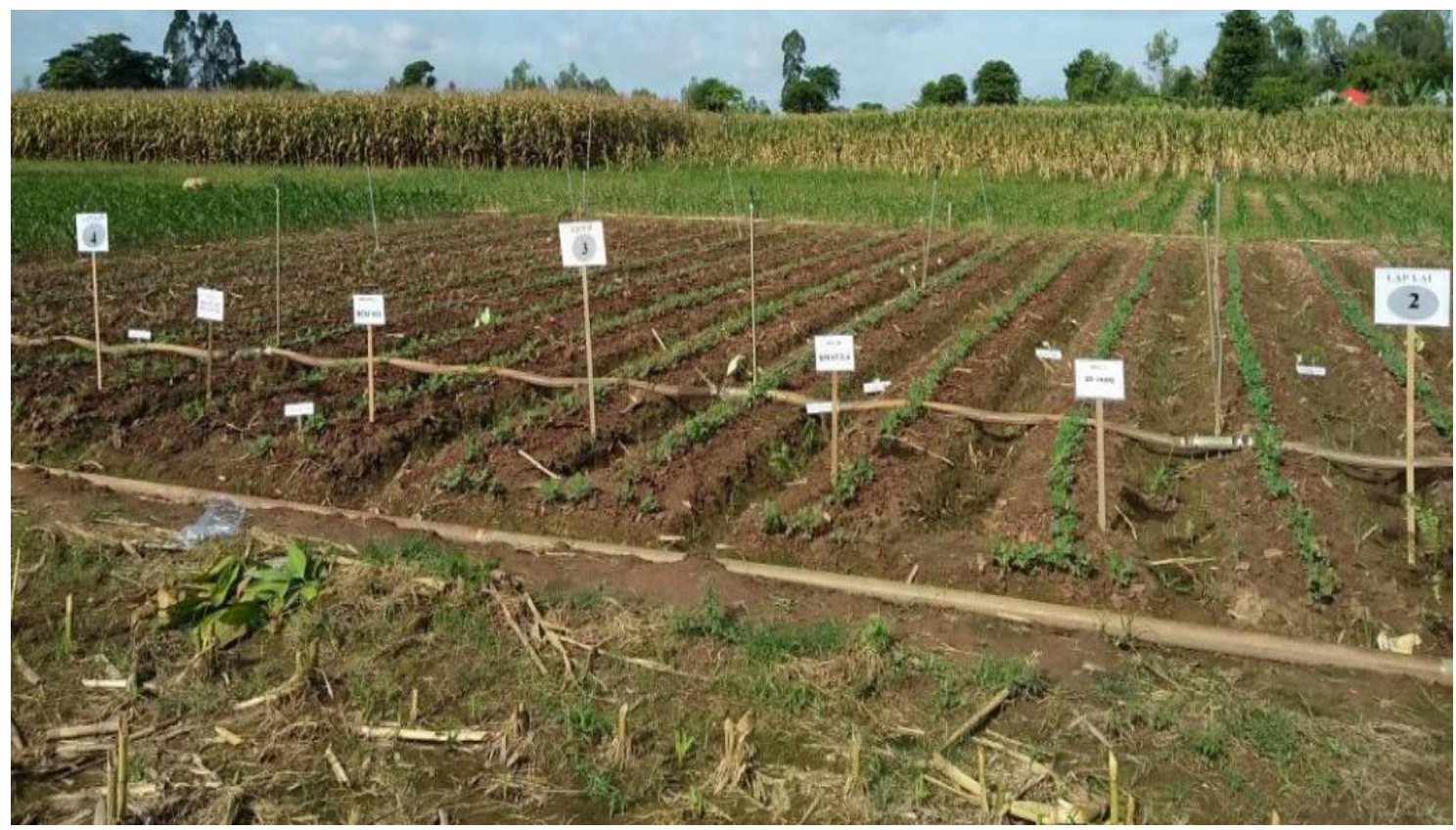

Figure 1 Field experiments in Quoc Thai commune, An Phu district, An Giang province.

\section{Data and statistical analysis}

The dry matter yield was recorded and the dried samples were digested in a mixture of nitric and perchloric acids. The digests were analyzed for As with a Varian Vista AX CCD inductively coupled plasma atomic emission spectrometer. After the harvest of plants, the soil was air-dried, well mixed, and passed through a $2 \mathrm{~mm}$ sieve. Soil $\mathrm{pH}$ and electrical conductivity (EC) were measured. All data were analyzed by the generalized linear model analysis of variance using Genstat v10 (VSN International Ltd, UK, 2007).

\section{Results and discussion}

\section{Soil properties}

\section{Total Arsenic}

The results in Table 1 show the average As concentration in the soils was $32.4 \mathrm{mg} . \mathrm{kg}^{-1}$ inside the dike and $13.8 \mathrm{mg} \cdot \mathrm{kg}^{-1}$ outside the dike in deep soil from $0-20 \mathrm{~cm}$ taken in surveyed areas. Arsenic concentrations of soils were very high, exceeding the As concentration in agricultural land limitation of $12 \mathrm{mg} . \mathrm{kg}^{-1}$ according to the Vietnamese allowed standard. Especially, the As concentration of deep well water was $540 \mu \mathrm{g} . \mathrm{L}^{-1}$, which exceeds As concentration allowed in water of $50 \mu \mathrm{g} . \mathrm{L}^{-1}$ according to the Vietnamese allowed standard. Farmers in Quoc Thai have been using As-contaminated drilled well water to irrigate plants, which causes As polluted soils. 
Table 1 Soil particle size distribution and chemical characteristics at the first of the experiment in soil depth $(0-20 \mathrm{~cm})$.

\begin{tabular}{|c|c|c|}
\hline Soil analysis & Characteristics & Results \\
\hline \multirow{3}{*}{ Mechanical analysis (\%) } & Clay & 36.5 \\
\hline & Silt & 60.7 \\
\hline & Sand & 2.84 \\
\hline \multirow{4}{*}{ Available nutrients } & Total P (\%) & 0.11 \\
\hline & Available P (mg.kg $\left.{ }^{-1}\right)$ & 16.0 \\
\hline & Total N (\%) & 0.150 \\
\hline & Available $\mathrm{K}\left(\mathrm{mg} \cdot \mathrm{kg}^{-1}\right)$ & 650 \\
\hline \multirow{2}{*}{ As $\left(\mathrm{mg} \cdot \mathrm{kg}^{-1}\right)$} & Inside the dike & 32.4 \\
\hline & Outside the dike & 13.8 \\
\hline As $\left(\mu g . L^{-1}\right)$ & Deep well water to irrigate & 540 \\
\hline
\end{tabular}

Soil pH: The experimented results at first did not show any significant difference from treatments (Table 2). However, there were significant differences at $1 \%\left(\mathrm{P}_{\text {value }}=0.01\right)$ among treatments. The highest $\mathrm{pH}$ value was had at NT1 and NT3. This could be due to the fact that the soil of the experimental site had a relatively high buffering capacity based on its high carbonate content ( 3 tons $\mathrm{CaO} \mathrm{ha}^{-1}$ ) and intercropped ferns. Some studies were found that As accumulation by Pityrogrammacalomelanos was optimum in the soil of $\mathrm{pH} 3.6$ [19]. Nevertheless, the results of this study demonstrate that remediation of As-contaminated mining soils, by this fern, can be improved by changing the soil pH from 4.6 to 6.8 [11].

Table $2 \mathrm{pH}$ at the first and end of the experiment in soil depth $(0-20 \mathrm{~cm})$.

\begin{tabular}{lcccccc}
\hline \multirow{2}{*}{ Treatments } & \multicolumn{2}{c}{ pH $_{\text {H2O }}$} & \multicolumn{2}{c}{ EC $\left(\boldsymbol{\mu S . \mathbf { c m } ^ { - 1 } )}\right.$} & \multicolumn{2}{c}{ OM (\%) } \\
\cline { 2 - 7 } & First & End & First & End & First & End \\
\hline NT1(3 tons CaO.ha ${ }^{-1}$ ) & 6.30 & $6.90^{\mathrm{c}}$ & 210 & $228^{\mathrm{b}}$ & 0.856 & $1.20^{\mathrm{b}}$ \\
NT2 (fern alternately with maize) & 6.31 & $6.40^{\mathrm{b}}$ & 213 & $242^{\mathrm{c}}$ & 0.855 & $1.34^{\mathrm{c}}$ \\
NT3 (3 tons CaO.ha ${ }^{-1}+$ fern) & 6.28 & $7.02^{\mathrm{c}}$ & 220 & $287^{\mathrm{d}}$ & 0.857 & $1.45^{\mathrm{d}}$ \\
NT4 (control) & 6.33 & $6.05^{\mathrm{a}}$ & 230 & $188^{\mathrm{a}}$ & 0.854 & $1.17^{\mathrm{a}}$ \\
\hline F & $N s$ & $* *$ & $n s$ & $* *$ & $n s$ & $* *$ \\
CV\% & 0.60 & 6.51 & 7.8 & 15.7 & 0.97 & 12.0 \\
\hline
\end{tabular}

*Values are the mean of four replicates. Means within each column having different letters are significantly different according to LSD at ns: No significant differences, $5 \%(*)$, and $1 \%(* *)$ level. 


\section{Total soluble salts (EC)}

Effects of conventional intercropped practices of ferns, maize, and lime incorporation on EC of soil at depths $0-20 \mathrm{~cm}$ are shown in Table 2. The EC of soil pre-treatments was from 210 to $230 \mu \mathrm{S} . \mathrm{cm}^{-1}$ at treatments. However, there were no significant differences among the treatments used in the $1^{\text {st }}$ experiment. On the contrary, there were significant differences among treatments found at the end of the experiment at $1 \%$. Furthermore, maximum EC of soil was obtained towards NT3 $\left(287 \mu \mathrm{S} . \mathrm{cm}^{-1}\right)$, while minimum was found towards NT4 $\left(188 \mu \mathrm{S} . \mathrm{cm}^{-1}\right)$, as compared with other treatments. However, EC of soil was significantly affected by intercropped practices between ferns and maize with applied incorporation with lime.

\section{Total organic matter (O.M.)}

There were no significant differences among treatments used in the first of the experiments on OM of soil at depths $0-20 \mathrm{~cm}$, shown in Table 2. On the contrary, there were significant differences among treatments used at the end of the experiment at $1 \%$. The highest soil organic matter content $(1.45 \%)$ was obtained by treatment 3 , a significant difference from all other treatments, while the lowest content $(1.17$ $\%$ ) was obtained by the control treatment (Table 2).The soil organic matter of the end of the experiment increased from 27.0 to $40.9 \%$ compared to the treatments of the first of the experiment. Ferns have a strong influence on humus in the soil. They not only increase the total amount, but also contribute to improving the quality of soil humus [20]. In general, the total content of soil organic matters (SOM) in all treatments with fern was significantly increased compared to the control. SOM always increased proportionally to the increasing rates of fern application. In particular, SOM increased from $2.16 \%$ in the control to $3.83 \%$ at the fern application rate of 45 tons/ha after one year of the experiment; from 2.27 to $4.15 \%$ after 2 years of the experiment, and from 2.97 to $4.45 \%$ after 3 years of the experiment. The lime amendment combined with inorganic fertilizers which increased SOM and calcium from lime [20,21]. Ferns application that increased SOM, humus and soil moisture raised the bulk density of soil and the quality and yield of crop [20,22].

The results presented in Table 3 show that there were significant differences at $5 \%$ among treatments of As concentrations in the soil before the experiment. The highest As concentration in soils before the experiment was $32.9 \mathrm{mg} \cdot \mathrm{kg}^{-1}$ and the lowest was $32.5 \mathrm{mg} \cdot \mathrm{kg}^{-1}$. Thereby, the source of cultivated land in An Phu district was seriously contaminated by As. Additionally, the As content in the soil after the experiment had a statistically significant difference at $1 \%$; the highest value was of 46.4 mg.kg ${ }^{-1}$ in treatment 1 , and the lowest was of treatment $2\left(27.1 \mathrm{mg} \cdot \mathrm{kg}^{-1}\right)$, with treatment 4 achieving 28.2 mg. $\mathrm{kg}^{-1}$, and the treatment of ferns combined with liming achieving $36.5 \mathrm{mg} \cdot \mathrm{kg}^{-1}$. In the T-test, the As concentration in the soil was significantly different at $1 \%$ in the pre- and post-experimental treatments. Lowest soil As concentrations were in treatment using only ferns and highest in treatment using lime only at the time of the experiment. This is explained by the fact that, in the lime treatments, the uptake of As was reduced in the stems and seeds of maize plants, so As was retained more in the soil than in the control treatments. As in soils in the control treatments were absorbed by the stems and seeds of mungbeans [22]. On the other hand, treatments that intercropped ferns with maize contained lower As concentration than others, because ferns absorbed As by its shoots, stems, and leaves [20]. This shows that the soil here was seriously contaminated with As due to the use of As-contaminated deep well water for cultivation. The As concentration in the soil exceeded the allowed concentration in agricultural soil of $12 \mathrm{mg} \cdot \mathrm{kg}^{-1}$. From there, lime combined with planting ferns effectively reduced As content in soil and its accumulation in the plant. According to prior study [23], ferns which were hyperaccumulator plants accumulated the high As content of four polluted soils. 
Table 3 Effects of liming and ferns on As concentrations in soil.

\begin{tabular}{lcc}
\hline \multirow{2}{*}{ Treatments } & Arsenic in the experiment soil $\mathbf{~ m g . k g}^{-\mathbf{1}}$ ) \\
\cline { 2 - 3 } & Before & After \\
\hline NT1(3 tons CaO.ha $\left.{ }^{-1}\right)$ & $32.6^{\mathrm{ab}}$ & $46.4^{\mathrm{d}}$ \\
NT2 (fern alternately with maize) & $32.6^{\mathrm{ab}}$ & $27.1^{\mathrm{a}}$ \\
NT3 (3 tons CaO.ha ${ }^{-1}+$ fern) & $32.5^{\mathrm{a}}$ & $36.5^{\mathrm{c}}$ \\
NT4 (control) & $32.9^{\mathrm{b}}$ & $28.2^{\mathrm{b}}$ \\
\hline F & $*$ & $* *$ \\
CV\% & 2.78 & 23.2 \\
\hline
\end{tabular}

*Values are the mean of four replicates. Means within each column having different letters are significantly different according to LSD at $5 \%(*)$ level.

\section{Crop traits}

Plant height of maize

Plant height after 20, 45 and 65 DAS showed no significant differences among treatments, but the harvested crop under treatments showed significantly differences at $1 \%$ (Table 4). The maximum height of plant $(269 \mathrm{~cm})$ was observed towards NT3, while the minimum $(237 \mathrm{~cm})$ was observed towards NT4 (control treatment). However, heights in treatment NT1 and NT2 were observed as 251 and $247 \mathrm{~cm}$, respectively. Plant height is a genetic characteristic that is modified by factors like the availability of moisture and nutrients at active growth stages. Results regarding plant height at harvest were influenced by liming and fern application and showed that plant height was affected significantly $(\mathrm{P}=0.01)$.

Table 4 Effects of liming and ferns on plant height of maize.

\begin{tabular}{lcccc}
\hline \multirow{2}{*}{ Treatments } & \multicolumn{4}{c}{ Plant height (cm) } \\
\cline { 2 - 5 } & 20 DAS & 45 DAS & 65 DAS & Harvest \\
\hline NT1(3 tons CaO.ha ${ }^{-1}$ ) & 66.3 & 186 & 217 & $251^{\mathrm{c}}$ \\
NT2 (fern alternately with maize) & 66.8 & 185 & 219 & $247^{\mathrm{b}}$ \\
NT3 (3 tons CaO.ha ${ }^{-1}+$ fern) & 66.6 & 191 & 222 & $269^{\mathrm{d}}$ \\
NT4 (control) & 66.3 & 185 & 219 & $237^{\mathrm{a}}$ \\
\hline F & $n s$ & $n s$ & $n s$ & $* *$ \\
CV\% & 1.63 & 2.28 & 0,94 & 4.78 \\
\hline
\end{tabular}

*DAS: days after sowing; * Values are the mean of four replicates. Means within each column having different letters are significantly different according to LSD at ns: no significant differences, $5 \%(*)$, and $1 \%(* *)$ level. 


\section{Yield and yield components}

\section{Plant biomass of maize}

Results of plant biomass after harvesting crop under treatments are shown in Table 5. The maximum biomass of maize plant $\left(17.7\right.$ tons.ha $\left.^{-1}\right)$ was observed towards NT3, while the minimum (15.0 tons.ha $^{-1}$ ) was observed towards NT4. However, treatments NT1 and NT2 were observed as 17.1 and 16.7 tons.ha $^{-1}$, respectively. Plant biomass is basically a genetic character that is modified by factors like the availability of moisture and nutrients at active growth stages [24]. Results regarding plant biomass at harvest as influenced by lime and fern application showed that plant biomass was affected significantly (P $=0.01)$.

\section{Weight of thousand grains}

Results of thousand grains weight cob after harvesting under treatments are shown in Table 5. The maximum weight of grains (320 g) was observed towards NT3, while the minimum (258 g) towards NT4. However, treatments NT1 and NT2 were observed as 313 and $301 \mathrm{~g}$, respectively. Thousand-grain weight of a crop has a vital role in the ultimate final grain yield; the results indicated that the highest weight of thousand-grains was observed towards NT3, while lowest under NT4. The combined effects of lime and fern on thousand-grain weight were found to be significant. The conventional treatment with lime and fern provided a favorable environment for plant growth, better root development, and plant populations; it gave better results than other methods in the experiment.

\section{Grains per cob}

Results of grains per cob after harvesting under treatments are shown in Table 5. The maximum number of grains (487 and 482), which was observed towards NT3 and NT1, respectively was significant differences at $\mathrm{P}=0.01$, while the minimum (350) were observed towards NT4. However, treatment NT2 was observed as 367 . The results showed that the conventional lime application with intercropped fern in As-contaminated soil significantly affected the grains $\operatorname{cob}^{-1}$. The interactive effects of lime and fern on grains $\operatorname{cob}^{-1}$ were found to be significant $(\mathrm{P}=0.01)$.

Table 5 Effects of liming and ferns on yield and yield components of maize.

\begin{tabular}{lcccc}
\hline \multicolumn{1}{c}{ Treatments } & $\begin{array}{c}\text { Plant biomass } \\
\left(\text { ton.ha }^{-1}\right)\end{array}$ & $\begin{array}{c}\text { Weight of } \\
\text { thousand } \\
\text { grains }(\mathbf{g})\end{array}$ & Grainscob $^{-1}$ & $\begin{array}{c}\text { Total grain } \\
\text { yield } \\
\text { ton.ha }^{-1} \text { ) }\end{array}$ \\
\hline NT1 $\left(3\right.$ tons CaO.ha $\left.{ }^{-1}\right)$ & $17.1^{\mathrm{c}}$ & $313^{\mathrm{ab}}$ & $482^{\mathrm{c}}$ & $10.8^{\mathrm{c}}$ \\
NT2 (fern alternately with maize) & $16.7^{\mathrm{b}}$ & $301^{\mathrm{b}}$ & $367^{\mathrm{b}}$ & $9.20^{\mathrm{b}}$ \\
NT3 (3 tons CaO.ha ${ }^{-1}+$ fern) & $17.7^{\mathrm{d}}$ & $320^{\mathrm{c}}$ & $487^{\mathrm{c}}$ & $11.2^{\mathrm{d}}$ \\
NT4 (control) & $15.0^{\mathrm{a}}$ & $258^{\mathrm{a}}$ & $350^{\mathrm{a}}$ & $8.70^{\mathrm{a}}$ \\
\hline F & $* *$ & $* *$ & $* *$ & $* *$ \\
CV (\%) & 6.26 & 8.76 & 15.5 & 11.0 \\
\hline
\end{tabular}

* Values are the mean of four replicates. Means within each column having different letters are significantly different according to LSD at ns: no significant differences, $5 \%(*)$, and $1 \%(* *)$ level. 


\section{Total grain yield}

The enhancement of the As-contaminated soil environment by lime application with an intercropped fern had significantly higher grain yields compared with the other treatments. Total grain yield after harvesting of the crop under treatments is shown in Table 5. The maximum yield (11.2 ton.ha $\left.{ }^{-1}\right)$ was obtained towards NT3, while the minimum $\left(8.7\right.$ ton.ha $\left.^{-1}\right)$ was obtained towards NT4. The highest yield was recorded by lime ( 3 ton.ha ${ }^{-1}$ ) with ferns. Maize production/yield can be significantly increased by the application of lime on soil [24].

Table 6 Effects of liming and ferns on some chemical traits of maize and ferns.

\begin{tabular}{lcccc}
\hline & \multicolumn{3}{c}{ Arsenic concentrations in plants } \\
\cline { 2 - 5 } \multicolumn{1}{c}{ Treatments } & \multicolumn{2}{c}{ Fern $\left(\mathbf{m g . k ^ { - 1 }}\right)$} & \multicolumn{2}{c}{ Maize $\left(\boldsymbol{\mu g} . \mathbf{~ k g}^{-1}\right)$} \\
\cline { 2 - 5 } & Stems & Roots & Stems & Seeds \\
\hline NT1 (3 tons CaO.ha $\left.{ }^{-1}\right)$ & - & - & $288^{\mathrm{a}}$ & $108^{\mathrm{b}}$ \\
NT2 (fern alternately with maize) & 237 & 65.9 & $355^{\mathrm{b}}$ & $120^{\mathrm{c}}$ \\
NT3 (3 tons CaO.ha ${ }^{-1}+$ fern) & 221 & 44.1 & $262^{\mathrm{a}}$ & $90.1^{\mathrm{a}}$ \\
NT4 (control) & - & - & $385^{\mathrm{c}}$ & $180^{\mathrm{d}}$ \\
\hline F & - & & $* *$ & $* *$ \\
\hline CV (\%) & - & & 15.4 & 25.3 \\
\hline
\end{tabular}

*Values are the mean of four replicates. Means within each column having different letters are significantly different according to LSD at ns: No significant differences, $5 \%(*)$, and $1 \%(* *)$ level.

As concentration in seeds, stems of maize in non-liming and fern experiments are always higher than other treatments of $3 \mathrm{CaO}$ tons.ha ${ }^{-1}$ and intercropped ferns. Results of As concentration in stems and seeds after harvesting under treatments are shown in Table 6. The highest As concentration of maize was $180 \mu \mathrm{g} . \mathrm{kg}^{-1}$ in seeds and $385 \mu \mathrm{g} . \mathrm{kg}^{-1}$ in stems in the control treatment, while the lowest As concentration (90.1 $\mu \mathrm{g} . \mathrm{kg}^{-1}$ in seeds and $262 \mu \mathrm{g} . \mathrm{kg}^{-1}$ in stems) was observed towards NT3. However, treatments NT1 and NT2 were observed as $108,120 \mu \mathrm{g} \cdot \mathrm{kg}^{-1}$ in seeds and $288,355 \mu \mathrm{g} \mathrm{kg}^{-1}$ in stems, respectively. Phytoremediation of arsenic-contaminated environments will involve growing the arsenic hyperaccumulator (Pteris vittata) in the contaminated environment, harvesting the arsenic-rich biomass and the safe disposal of the biomass [11,23]. Results of As concentration in stems and roots of ferns after harvesting under treatments are shown in Table 6. The As concentrations of stems and roots (237 and $\left.65.9 \mathrm{mg} \cdot \mathrm{kg}^{-1}\right)$ and $\left(221\right.$ and $\left.44.1 \mathrm{mg} \cdot \mathrm{kg}^{-1}\right)$ were observed towards NT2 and NT3, respectively. A field study on phytoremediation of an arsenic-contaminated soil showed that it would take eight years to reduce the arsenic in the soil to safe levels by using $P$. vittata [11]. However, to the best of our knowledge, there has been no proper way to categorize crops as low-As or high-As-accumulating until now. While working toward such a categorization technique, BCF of As, and the stability of As accumulated among crop types or cultivars, should be considered as factors of significant priority. 


\section{Conclusions}

Application of lime and ferns had positive influences on soil $\mathrm{pH}, \mathrm{EC}, \mathrm{OM}$, yield and yield components of the maize tested in this study. The yield difference between the application of lime and intercropped ferns was marginal. Moreover, the arsenic contents in soil, stems, and seeds were lower than that of the control. Ferns that absorbed As from soil to stems and roots decreased a large amount of As content in soil. Therefore, to reduce As concentrations in soil and in plantsin As-contaminated crop soils, in order to reduce production cost and increase soil and maize quality, the wide application of lime ( 3 ton.h $\mathrm{a}^{-1}$ ) and intercropped ferns is recommended. It is highly recommended that people who do not use As-contaminated well water to irrigate their crops use the fern application to reduce As concentration in soil.

\section{Acknowledgements}

This research was supported by the An Giang University (AGU). We thank the Leadership of Faculty of Agriculture and Natural Resources, AGU, for excellent technical assistance, and the Masters students who helped to complete this experiment.

\section{References}

[1] JM Rosas-Castor, JL Guzmán-Mar, A Hernández-Ramírez, MT Garza-González and L HinojosaReyes. Arsenic accumulation in maize crop (Zea mays): A review. Sci. Total Environ. 2014; 488489, 176-87.

[2] X Liu, HY Feng, JW Fu, Y Chen, Y Liu and LQ Ma. Arsenic-induced nutrient uptake in Ashyperaccumulator Pteris vittata and their potential role to enhance plant growth. Chemosphere 2018; 198, 425-31.

[3] Z Zhao, H Zhang, Z Fu, H Chen, Y Lin, P Yan, W Li, H Xie, Z Guo, X Zhang and J Tang. Geneticbased dissection of arsenic accumulation in maize using a genome-wide association analysis method. Plant Biotechnol. J. 2018; 16, 1085-93.

[4] XY Xiao, TB Chen, XY Liao, XL Yan, H Xie, B Wu and LX Wang. Comparison of concentrations and Bioconcentration factors of arsenic in vegetables, grain and oil crops in China. Acta Scientiae Circumstantial 2009; 29, 291-6.

[5] XX Cao, LY Bai, XB Zeng, JZ Zhang, YN Wang, CX Wu and SM Su. Is maize suitable for substitution planting in arsenic-contaminated farmlands? Plant Soil Environ. 2019; 65, 425-34.

[6] D Ding, WH Li, GL Song, HY Qi, JB Liu and JH Tang. Identification of QTLs for arsenic accumulation in maize (Zea mays L.) using a RIL population. PLoS One 2011; 6, e25646.

[7] ZJ Fu, WH Li, XL Xing, MM Xu, XY Liu, HC Li, YD Xue, ZH Liu and JH Tang. Genetic analysis of arsenic accumulation in maize using QTL mapping. Sci Rep. 2016; 6, 21292.

[8] EA Ruíz-Huerta, AG Varela, JM Gómez-Bernal, F Castillo, M Avalos-Borja, BS Gupta and N Martínez-Villegas. Arsenic contamination in irrigation water, agricultural soil and maize crop from an abandoned smelter site in Matehuala, Mexico. J. Hazard. Mater. 2017; 339, 330-9.

[9] H Ali, E Khan and MA Sajad. Phytoremediation of heavy metals: Concepts and applications. Chemosphere 2013; 91, 869-81.

[10] R Requejo and M Tena. Influence of glutathione chemical effectors in the response of maize to arsenic exposure. J. Plant Physiol. 2012; 169, 649-56.

[11] P Zeng, Z Guo, X Xiao, C Peng, W Feng, L Xin, and Z Xu. Phytoextraction potential of Pteris vittata $\mathrm{L}$. co-planted with woody species for $\mathrm{As}, \mathrm{Cd}, \mathrm{Pb}$ and $\mathrm{Zn}$ in contaminated soil. Sci. Total Environ. 2019; 650, 594-603.

[12] FJ Zhao, SP McGrath and AA Meharg. Arsenic as a food chain contaminant: Mechanisms of plant uptake and metabolism and mitigation strategies. Ann. Rev. Plant Biol. 2010; 61, 535-59.

[13] P Jankong, P Visoottiviseth and S Khokiattiwong. Enhanced phytoremediation of arseniccontaminated land. Chemosphere 2007; 68, 1906-12. 
[14] YY Sun, RL Liu, XB Zeng, QM Lin, LY Bai, LF Li, SM Su and YN Wang. Reduction of arsenic bio availability by amending seven inorganic materials in arsenic-contaminated soil. J. Integr. Agr. $2015 ; 14,1414-22$.

[15] BE Ifon, ACF Togbé, LAS Tometin, F Suanon and A Yessoufou. Metal-contaminated soil remediation: Phytoremediation, chemical leaching and electrochemical remediation. Intechopen, 2019.

[16] N Bolan and VP Duraisamy. Role of inorganic and organic soil amendments on immobilization and phyto availability of heavy metals: A review involving specific case studies. Aust. J.Soil Res. 2015; 41, 533-55.

[17] DH Moon, D Dermatas and N Menounou. Arsenic immobilization by calcium-arsenic precipitates in lime treated soils. Sci. Total Environ. 2014; 330, 171-85.

[18] NV Chuong and NT Chinh. Effects of lime and rice husk ash on total arsenic content in soybean grown inside the dike at An Phu district, An Giang province. J. Vietnam Agr. Sci. Tech.2018; 7, 2630 .

[19] BTK Anh, DD Kim, P Kuschk, TV Tua, NT Hue and NN Minh. Effect of soil pH on as hyperaccumulation capacity in fern species, Pityrogrammacalomelanos. J. Environ. Biol. 2013; 34, 237-42.

[20] NX Cu and TTT Thu. The effects of fern (Gleichenia linearis) mulching on soil properties, humus substance and microbial fauna in soils growing tea in Phu Tho Province, Vietnam. Int. J. Sci. Res. $2014 ; 3,18-23$.

[21] ACAC Filho, CJ Penn, CAC Crusciol and JC Calonego. Lime and phosphogypsum impacts on soil organic matter pools in a tropical Oxisol under long-term no-till conditions. Agr. Ecosyst. Environ. 2017; 241, 11-23.

[22] NV Chuong and NN Hung. Research on mitigating of rice, maize, and mung beans uptake of cadmium in An Phu district, An Giang province. Sci. Tech. J. Agr. Rural Dev. 2015; 1, 73-7.

[23] AO Fayiga and LQ Ma. Arsenic U=uptake by two hyperaccumulator ferns from four arsenic contaminated soils. Water, Air Soil Pollution 2005; 168, 71-89.

[24] S Fahad, AA Bajwa, U Nazir, SA Anjum, A Farooq, A Zohaib, S Sadia, W Nasim, S Adkins, S Saud, MZ Ihsan, H Alharby, C Wu, D Wang and J Huang. Crop production under drought and heat stress: Plant responses and management options. Front. Plant. Sci. 2017; 8, 1147. 